\title{
Synthesis and characterization of $\mathrm{Mo}_{2} \mathrm{C}$ based materials over activated carbon derived from sewage sludge pyrolysis for catalytic applications
}

\section{(Síntese e caracterização de materiais à base de carbeto de molibdênio suportado em carvão ativado originado da pirólise do lodo de esgoto)}

\author{
A. C. Alexandrino ${ }^{*}$, J. F. de Sousa ${ }^{1}$, C. P. de Souza ${ }^{1}$, C. P. B. de Araújo ${ }^{1}$, M. V. M. Souto ${ }^{2}$ \\ ${ }^{1}$ Universidade Federal do Rio Grande do Norte, Centro de Tecnologia, \\ Programa de Pós-Graduação em Engenharia Química, \\ Laboratório de Materiais Nanoestruturados e Reatores Catalíticos, \\ Av. Sen. Salgado Filho, 59078-970, Natal, RN, Brazil \\ ${ }^{2}$ Universidade Federal do Rio Grande do Norte, Centro de Tecnologia, Programa de Pós-Graduação em Ciência \\ e Engenharia de Materiais, Laboratório de Materiais Nanoestruturados e Reatores Catalíticos, Brazil
}

\begin{abstract}
Transition metal carbides have been successfully used as substitute materials for conventional noble metal catalyst in several important industrial reactions due to their interesting physicochemical properties. Surface structure, chemical composition and metal-support interactions, as well as processing conditions, are of utmost importance in the use of such materials in catalysis. The present study aimed to synthesize and evaluate pure molybdenum carbide with and without support, and bimetallic Mo-Ni carbide over a carbon active support derived from sewage sludge pyrolysis. The support was chemically (KOH) and physically (thermal treatment) activated before use. TG/DTG, XRD, XRF, SEM, BET and particle size evaluation were performed, together with adsorption/desorption isotherms. Results indicated that the applied synthesis method was adequate for the obtainment of pure materials. The increase in surface area of the support was significant, from 13 to $141 \mathrm{~m}^{2} . \mathrm{g}^{-1}$ after the thermal and chemical treatment; also, supporting $\mathrm{Mo}_{2} \mathrm{C}$ over carbon provided an increase from 45 to $73 \mathrm{~m}^{2} \cdot \mathrm{g}^{-1}$ in surface area, which indicated its potential as a catalytic material as well as the effectiveness of the applied methodology.

Keywords: molybdenum carbide, activated carbon, fixed bed reactor, chemical activation, characterization.
\end{abstract}

Resumo

Carbetos de metais de transição vêm sendo aplicados com sucesso em substituição aos catalisadores convencionais principalmente devido às suas propriedades físico-químicas. A estrutura da superficie, composição química, interação metal-suporte e condições de processamento são essenciais na aplicação dos carbetos para esse fim. O presente estudo teve como objetivo sintetizar, em leito fixo, a partir de reação gás-sólido, carbeto de molibdênio puro, bimetálico (Mo-Ni) e suportado em carvão ativado obtido através da pirólise do lodo de esgoto, e compará-los visando aplicação em reações catalíticas. O carvão foi submetido a um processo de ativação química utilizando $\mathrm{KOH}$ e tratamento térmico. Os materiais foram caracterizados através das análises de TG, DRX, FRX, MEV, área superficial e volume de poros através do método BET e análise granulométrica. As isotermas de adsorção e dessorção foram também obtidas para os diferentes materiais. Os resultados mostraram que a metodologia utilizada para síntese dos materiais foi satisfatória, principalmente tendo em vista o aumento significativo da área superficial dos materiais, de 13 para $141 \mathrm{~m}^{2} / \mathrm{g}$, quando o carvão foi tratado com KOH bem como quando o mesmo foi adicionado ao carbeto (de $45 \mathrm{para} 73 \mathrm{~m} / \mathrm{g}$ ), o qual pode justificar uma aplicação catalítica.

Palavras-chave: carbetos de molibdênio, carvão ativado, reator de leito fixo, ativação química, caracterização.

\section{INTRODUCTION}

The discovery of WC as an active catalyst for the isomerization of 2,2-dimethylpropane in hydrogen atmosphere in the 1970's was the starting point for the use of carbide based materials in heterogeneous catalysis [1]. From then on, studies have continuously demonstrated that the catalytic properties of transition metal carbides, especially $\mathrm{W}$ and Mo, are similar to noble metal catalyst for several important industrial reactions such as oil refining ones: hydrogenation, isomerization, hydrogenolysis of hydrocarbons, etc. These materials have also been proved interesting for hydrotreatment reactions for the removal of heteroatoms of the transportation fuels for environmental compliance on the emission of nitrogen and sulfur compounds, such as hydrodesulfurization (HDS) and hydrodenitrogenation (HDN) [2,3].

Surface structure, chemical composition and processing 
conditions are variables of utmost importance for carbides' industrial applications, not only in the catalytic field. Gassolid reactions between carbon (gas) and metal sources (solid) are able to produce carbides with good control over particle size, shape and crystal structure $[4,5]$ due to greater fluid-particle interaction. In metallurgical route, for instance, carbon diffuses in a solid through liquid metal, whereas in the gas-solid process, it diffuses as a gas phase into the solid, which enhances mass transfer velocities. The TPR (temperature programmed reaction) method, developed in [6], is the most used gas-solid route for the synthesis of these materials in laboratory scale. In this process a precursor is subject to the flow of a gas mixture containing both carburizing and reducing agents $\left(\mathrm{CH}_{4} / \mathrm{H}_{2}\right)$ whilst the temperature is linearly increased from room temperature to established reaction temperature. These process products are usually nanoscale materials. For the use of such powders in industrial scale reactors, however, high pressure drops are expected in FCC (fluid catalytic cracking) and HDT (catalytic hydrotreating) units due to the great particle interactions (van der Walls forces), which may cause bed agglomeration and instability. The use of a support material for the active catalyst phases is, therefore, essential for the effective use of these materials in large scale process due to the decreased pressure drop caused in the reactive systems. In this sense, the support is important for the catalysts behavior as a dispersion of the active phase is promoted, and as it plays a role in the catalytic process due to its surface properties and composition [7].

Activated carbon can be prepared from porous carbon materials that present a non-graphitic microcrystalline shape, and must undergo physical and chemical processes in order to increase its porosity. These materials are produced in two steps: carbonization from a precursors' pyrolysis followed by acid or basic activation. Carbonization consists of a thermal treatment of the precursor in an inert atmosphere at a temperature over $200{ }^{\circ} \mathrm{C}$, whereas activation is related to subjecting the carbonized material to secondary reactions, aiming an increase in superficial area [8]. Activated carbon (A.C) is a well-known and important industrial adsorbing material, having its adsorption characteristics put to use in several processes, such as water treatment, deodorization, gas purification, protection filters, catalysts support (as in the case of this paper) and others. These applications are mainly due to its high porosity (micro, meso and macropores) coupled with its high thermal and chemical stability [9].

The addition of a second metal to the carbide structure, in order to synthesize doped or bimetallic carbides, represents the possibility of increasing catalytic efficiency and activity, due to and increased density of the available active sites [10]. Therefore, this paper aims to synthesize and characterize pure molybdenum carbide and molybdenum carbide based materials (with nickel addition or not) supported on activated carbon obtained from the pyrolysis of domestic sewage sludge, followed by thermal and chemical treatments, aiming a catalytic use of such materials.

\section{MATERIALS AND METHODS}

Synthesis and washing of the carbon: domestic sewage sludge underwent pyrolysis in a rotating cylinder reactor at $500{ }^{\circ} \mathrm{C}$ with $\mathrm{N}_{2}$ flow at a rate of $50 \mathrm{~mL} / \mathrm{min}$ [11] in order to produce the carbonaceous material used in this study. Biooil residues, however, were observed in the carbon powder obtained from this process. As this could compromise the following steps of the activation process and the use of the material as a support for the catalysts, the material was successively washed with dichloromethane and ethanol. Washing of the carbon powder with dichloromethane $\left(\mathrm{CH}_{2} \mathrm{Cl}_{2}\right.$, P.A., Synth, $\left.99.5 \%\right)$ consisted of the mixture of the powder with the reactant in a beaker under constant stirring for $30 \mathrm{~min}$ at ambient temperature, followed by vacuum filtering. This process was repeated until no trace color of bio-oil could be noted on the filtered solution. The process was then repeated using ethanol as reactive media at $60^{\circ} \mathrm{C}$ for $30 \mathrm{~min}$ in order to remove dichloromethane traces on the powder. The solution was vacuum filtered and distilled water was added until $\mathrm{pH}$ of approximately 6.5 on the filtered solution was verified. Once washed, the carbon powder was dried in muffle furnace at $100{ }^{\circ} \mathrm{C}$ for $1440 \mathrm{~min}$.

Carbon activation: chemical and physical activation of the carbon material followed the methodologies proposed in $[12,13]$ with adjusts. To the washed and dried carbon material, a $\mathrm{KOH}$ solution ( $2 \mathrm{M}$, Vetec, $85 \%$ ) was added in a 1:2 (carbon: $\mathrm{KOH}$ ) rate. The solution was stirred for $2 \mathrm{~h}$ at ambient temperature, filtered and dried in a kiln at $100{ }^{\circ} \mathrm{C}$ for $1440 \mathrm{~min}$. The produced material was then subject to thermal treatment in horizontal tube furnace (FT 1200/H-3z, Fortelab) at $500{ }^{\circ} \mathrm{C}$ for 120 min under $\mathrm{N}_{2}$ (Linde, $99 \%$ ) flow (1 L/min) with heating rate of $10{ }^{\circ} \mathrm{C} / \mathrm{min}$. After this, $\mathrm{KOH}$ removal and neutralization was performed according to the methodology described in $[12,14]$. The carbon material was

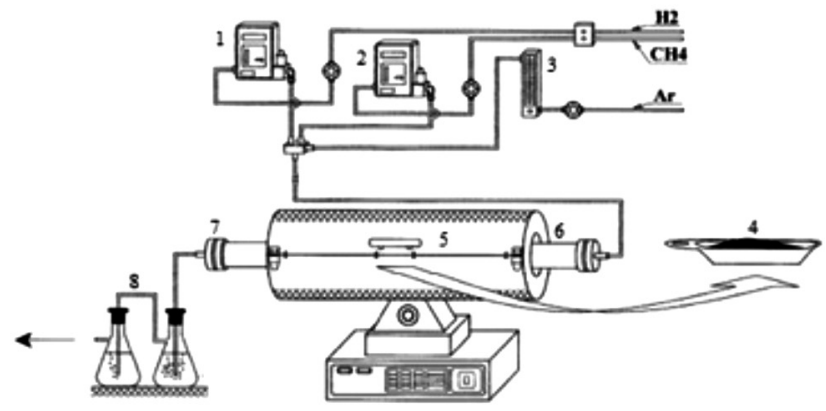

Figure 1: Resistance furnace coupled with alumina fixed bed reactor: 1,2) mass flow controllers for $\mathrm{H}_{2}$ and $\mathrm{CH}_{4} ; 3$ ) argon flow meter; 4) alumina crucible; 5) resistance furnace; 6) alumina fixed bed reactor; 7) sealing; 8) bubble systems.

[Figura 1: Forno resistivo bipartido de leito fixo: 1,2) controlador mássico de $\mathrm{H}_{2}$ e $\mathrm{CH}_{4}$; 3) rotâmetro para argônio; 4) navícula de alumina; 5) forno bipartido; 6) reator tubular de alumina; 7) flanges de vedação; 8) borbulhadores de gás.] 
washed with a diluted $\mathrm{HCl}$ (P.A., Vetec) solution at a 1:5 rate under stirring at $60^{\circ} \mathrm{C}$ for $30 \mathrm{~min}$ and then filtered. The solid was then successively washed with distilled water at $100{ }^{\circ} \mathrm{C}$ for 30 min under stirring, until the leach water reached a $\mathrm{pH}$ of 7 . The powder was then dried in muffle furnace for 1440 $\min$ at $100^{\circ} \mathrm{C}$.

Molybdenum carbide synthesis: pure molybdenum carbide was obtained via gas-solid reaction in a fixed bed reactor coupled with a resistance furnace (EDG Túnel FTHI40, Brazil) with the apparatus presented in Fig. 1 by the use of TPR method according to the methodology proposed in [15] using ammonium heptamolybdate $\left[\left(\mathrm{NH}_{4}\right)_{6} \mathrm{Mo}_{7} \mathrm{O}_{24} \cdot 4 \mathrm{H}_{2} \mathrm{O}\right]$ AHM (Sigma-Aldrich, 99.98\%) as a starting material.

Bimetallic Mo-Ni carbide over A.C synthesis: bimetallic Mo-Ni carbide over A.C synthesis was performed according to the methodology proposed in [16]. The nickel impregnation step was carried out by using a solution of deionized water, activated carbon, nickel nitrate $\left[\mathrm{Ni}\left(\mathrm{NO}_{3}\right)_{2} \cdot 6 \mathrm{H}_{2} \mathrm{O}\right]$ (SigmaAldrich) and AHM in order to produce the carbo-reduction reaction's precursor.

$\mathrm{Mo}_{2} \mathrm{C} / \mathrm{A}$.C synthesis: molybdenum carbide supported on activated carbon was synthesized by wet impregnation of activated carbon with AHM, followed by the same reactive and thermal process applied for the synthesis of bimetallic Mo-Ni/A.C.

Materials' characterization: AHM precursor and activated carbon were subject to thermogravimetric evaluation (TG, Netzsch, STA 449 F3 Jupiter $^{\circledR}$, argon flow, from $30-800{ }^{\circ} \mathrm{C}$, heating rate of $5{ }^{\circ} \mathrm{C} / \mathrm{min}$ ), to evaluate its mass loss behavior and crystal structure modifications. Both the molybdenum derived carbides and the activated carbon powders were subject to X-ray diffraction (XRD) analysis (Shimadzu, XRD-7000, CuKa, $30 \mathrm{~mA}$ and $60 \mathrm{kV}$ ) to evaluate crystal structure. X-ray fluorescence (XRF) analysis (Shimadzu, EDX-720, air atmosphere) were performed for chemical composition evaluation, scanning electron microscopy (SEM, Hitachi, Tabletop Microscope TM-3000), in order to assess morphological aspects, and surface area and pore structure were evaluated according to Brunauer, Emmet and Teller (BET, Micrometrics, ASAP 2000) methodology. Particle size distribution was verified by laser granulometry (Microtrac, S3500).

\section{RESULTS AND DISCUSSION}

Thermogravimetric evaluation (TG): Fig. 2a presents the thermal profile for AHM. It was verified that the material lost mass in three temperature ranges: from 112$135{ }^{\circ} \mathrm{C}$ and $212-234{ }^{\circ} \mathrm{C}$ water and $\mathrm{NH}_{3}$ evolution occurred. AHM decomposition started at $280^{\circ} \mathrm{C}$ and continued until $\sim 330^{\circ} \mathrm{C}$, being reduced to $\mathrm{MoO}_{3}$ with a total mass loss of approximately $16 \%$. All events were endothermic. Fig. $2 \mathrm{~b}$ presents the thermal profile for the carbon material derived from the pyrolysis of sewage sludge. It can be seen that thermal stability was achieved over $500^{\circ} \mathrm{C}$. This temperature was, therefore, used as minimum required temperature for the thermal treatment applied on the physical activation of this
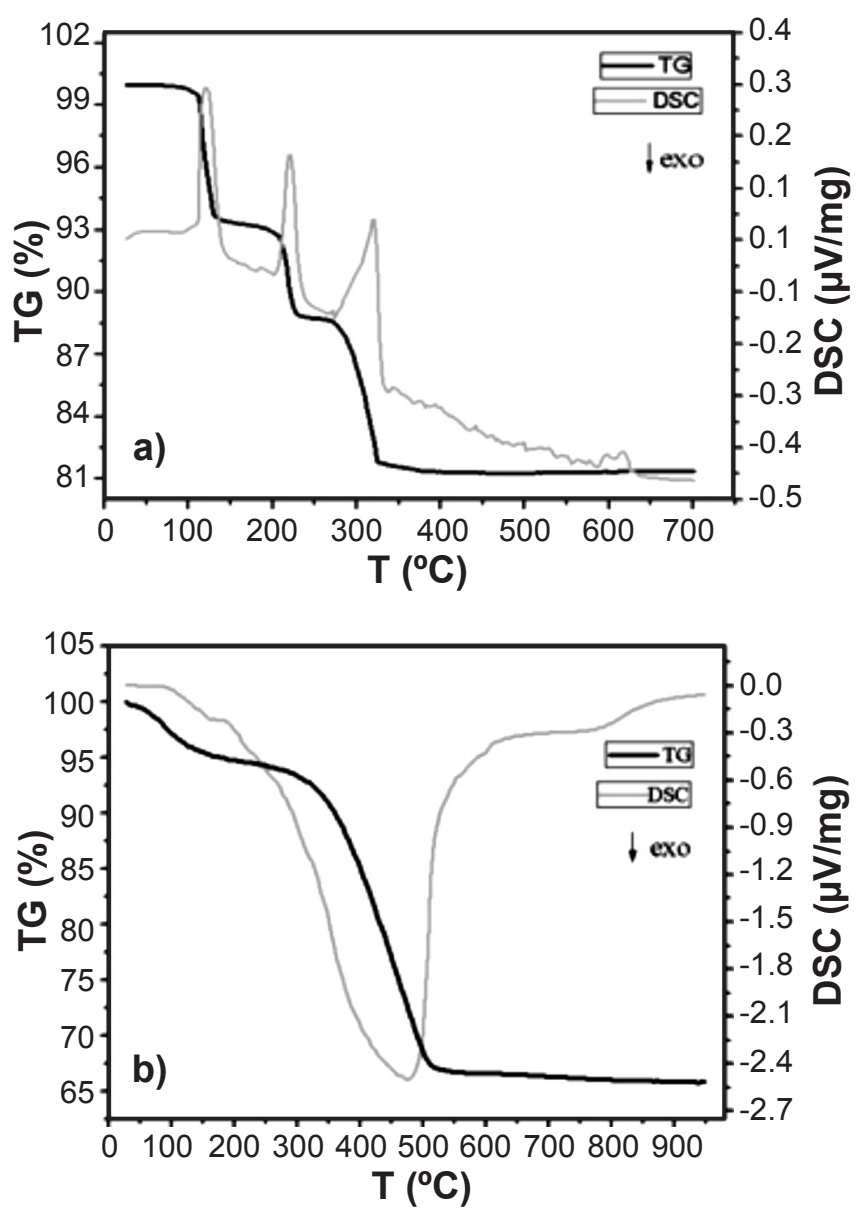

Figure 2: TG and DSC curves for: (a) AHM; and (b) carbon originated from the pyrolysis of sewage sludge.

[Figura 2: Curvas de TG e DSC do: (a) HMA; e (b) carvão originado da pirólise do lodo de esgoto.]

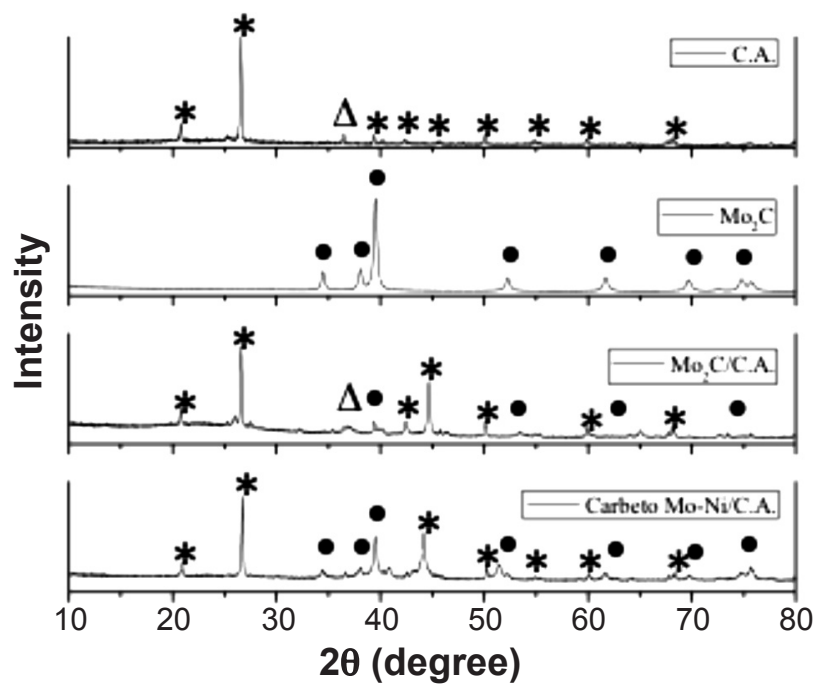

Figure 3: X-ray diffraction patterns for the obtained powders (* - A.C's quartz; $\boldsymbol{\Delta}$ - microcline; $\bullet-\mathrm{Mo}_{2} \mathrm{C} ; \triangle$ - Ni).

[Figura 3: Difratogramas de raios $X$ dos pós obtidos (* - quartzo do C.A.; $\boldsymbol{\Delta}$ - microclínio; • - Mo ${ }_{2} \mathrm{C} ; \triangle$ - Ni).]

material. Carbon mass loss was mainly due to lignocellulose derived materials present in the structure, and accounted for approximately $32 \%$ of the total mass. 
X-ray diffraction analysis: XRD patterns for the A.C, $\mathrm{Mo}_{2} \mathrm{C}, \mathrm{Mo}_{2}$ C/A.C and Mo-Ni carbide over A.C are presented in Fig. 3. Crystal phases were identified with X'Pert HighScore Plus software. The activated carbon support presented peaks related to carbon ashes which is the main residue of carbonaceous materials degradation. Ashes were composed, in majority, of silicon, aluminum, iron, potassium and calcium, which belong to the quartz $\left(\mathrm{SiO}_{2}\right)$ and microcline $\left(\mathrm{KAlSi}_{3} \mathrm{O}_{8}\right)$ phases found in the presented pattern. XRF analysis (shown below) confirmed the presence of such elements. $\mathrm{Mo}_{2} \mathrm{C}$ was obtained as a single phase, with well-defined peaks related to molybdenum carbide when produced in the absence of the support. $\mathrm{Mo}_{2} \mathrm{C} / \mathrm{A}$.C, on the other hand, presented both $\mathrm{Mo}_{2} \mathrm{C}$ peaks and those relative to the activated carbon material as expected. On the Mo-Ni carbide supported on A.C, it was noted, as well, the presence of metallic Ni peaks (highlighted).

Crystal sizes estimates were performed according to Scherrer's methodology form the XRD data. Table I summarizes these estimates and presents the crystal structures and reference patterns used in the phase identification step. The synthesis of $\mathrm{Mo}_{2} \mathrm{C}$ over activated carbon lead to a slight decrease in crystal sizes in comparison to pure $\mathrm{Mo}_{2} \mathrm{C}$

Table I - Crystal size estimate and crystal structure for the produced materials.

[Tabela I - Tamanho de cristal estimado e estrutura cristalina dos materiais sintetizados.]

\begin{tabular}{cccc}
\hline Sample & $\begin{array}{c}\text { Crystal } \\
\text { size }(\mathrm{nm})\end{array}$ & $\begin{array}{c}\text { Reference } \\
\text { pattern ICCD }\end{array}$ & $\begin{array}{c}\text { Crystal } \\
\text { structure }\end{array}$ \\
\hline $\begin{array}{c}\text { A.C } \\
\mathrm{Mo}_{2} \mathrm{C}\end{array}$ & 60.44 & $33-1161$ & Hexagonal \\
$\mathrm{Mo}_{2} \mathrm{C} / \mathrm{A} . \mathrm{C}$ & 41.22 & $72-1683$ & Orthorhombic \\
$\begin{array}{c}\text { Mo-Ni } \\
\text { carbide/A.C }\end{array}$ & 62.91 & $71-2315$ & Hexagonal \\
\hline
\end{tabular}

produced without support; this difference however was not a major one. The addition of the second metal to the carbide structure, on the other hand, promoted a significant increase in particle size. This may be due to the presence of $\mathrm{Ni}$, in some extent, in the carbide structure, which can lead to cell deformation in order to accommodate it.

$X$-ray fluorescence: Table II presents elemental composition of the pure molybdenum carbide, activated carbon and supported materials' samples. It can be noted that iron presents the highest composition on the inorganic share of activated carbon, followed by silicon and aluminum. It is noteworthy the significant decrease in composition of such elements after the carbo-reduction reaction, probably due to leaching by the gas phase or sublimation during heating. The addition of $\mathrm{Ni}$ in the Mo-Ni bimetallic carbide over activated carbon compound can also be confirmed.

Scanning electron microscopy: in Figs. $4 \mathrm{a}$ and 4b, SEM images of the activated carbon powder are presented. It can be seen that the A.C presented pores in its structure,
Table II - XRF verified elemental composition (wt $\%$ ). [Tabela II - Composição elementar de análise de FRX $(\%$ em massa).]

\begin{tabular}{ccccc}
\hline Element & $\mathrm{Mo}_{2} \mathrm{C}$ & $\mathrm{A} . \mathrm{C}$ & $\mathrm{Mo}_{2} \mathrm{C} / \mathrm{A} . \mathrm{C}$ & $\begin{array}{c}\mathrm{Mo}-\mathrm{Ni} \\
\text { carbide/A.C }\end{array}$ \\
\hline $\mathrm{Mo}$ & 100.00 & - & 46.12 & 42.80 \\
$\mathrm{Ni}$ & - & 0.14 & 0.06 & 28.40 \\
$\mathrm{Fe}$ & - & 66.94 & 26.25 & 8.77 \\
$\mathrm{Si}$ & - & 18.68 & 16.26 & 11.56 \\
$\mathrm{Al}$ & - & 6.96 & 5.43 & 3.33 \\
$\mathrm{Ti}$ & - & 2.36 & 1.93 & 1.05 \\
$\mathrm{~K}$ & - & 1.66 & 2.28 & 1.44 \\
$\mathrm{Zn}$ & - & 0.88 & 0.23 & 0.10 \\
$\mathrm{Ca}$ & - & 0.73 & 0.92 & 0.94 \\
$\mathrm{Zr}$ & - & 0.65 & 0.08 & 0.09 \\
$\mathrm{Cr}$ & - & 0.49 & 0.27 & 0.14 \\
$\mathrm{Cu}$ & - & 0.34 & 0.10 & 0.25 \\
Others & - & 0.17 & 0.05 & 1.14 \\
\hline
\end{tabular}

which is an indicative of high surface areas (Table III). According to [8], the A.C structure can be represented as sheets of aromatic rings with empty spaces between them, which produce the pores seen in Figs. 4a and 4b. Figs. 4c and 4d shows AHM images. An irregularly shaped powder with sizes that greatly varies can be seen in both images. The molybdenum carbide powder presented in Figs. 4e and $4 \mathrm{f}$ exhibits a highly agglomerated characteristic, being those agglomerates formed of particles with undefined shape. This behavior was observed by other authors [17] who also found an agglomerated material as the product of carbo-reduction reaction $\left(\mathrm{Mo}_{2} \mathrm{C}\right)$ at $660{ }^{\circ} \mathrm{C}$ of AHM. In Figs. $4 \mathrm{~g}$ and $4 \mathrm{~h}$ typical $\mathrm{Mo}_{2} \mathrm{C}$ irregularly shaped particles can be seen, as well as agglomerates with presence of pores, which were also observed in A.C SEM evaluation (Fig. 4b). These observations indicated synergetic relation between these phases. In the morphology found in Figs. $4 \mathrm{i}$ and $4 \mathrm{j}$ for bimetallic Mo-Ni carbide over A.C it can be observed the presence of dispersed metal particles over the support, as well as the presence of pores and agglomerates, characteristics of the support.

Surface area and pore volume evaluation: Table III presents the BET surface area evaluation as well as pore size estimates. The attained results confirmed SEM evaluation. The highest specific surface areas were observed for the activated carbon and supported molybdenum carbide. As it can be noted, upon activation the carbon surface area increased over 10 times in comparison to non-activated carbon. This is due to the effective $\mathrm{KOH}$ action and the thermal activation process $\left(\mathrm{N}_{2}\right.$ atmosphere). According to [18], $\mathrm{KOH}$, used in the chemical step of the activation process, reduces to metal $\mathrm{K}$ in temperatures above its melting point, and penetrates carbon's lamellae structure, thus favoring an increase in final porosity and surface area. Molybdenum carbide powder also 

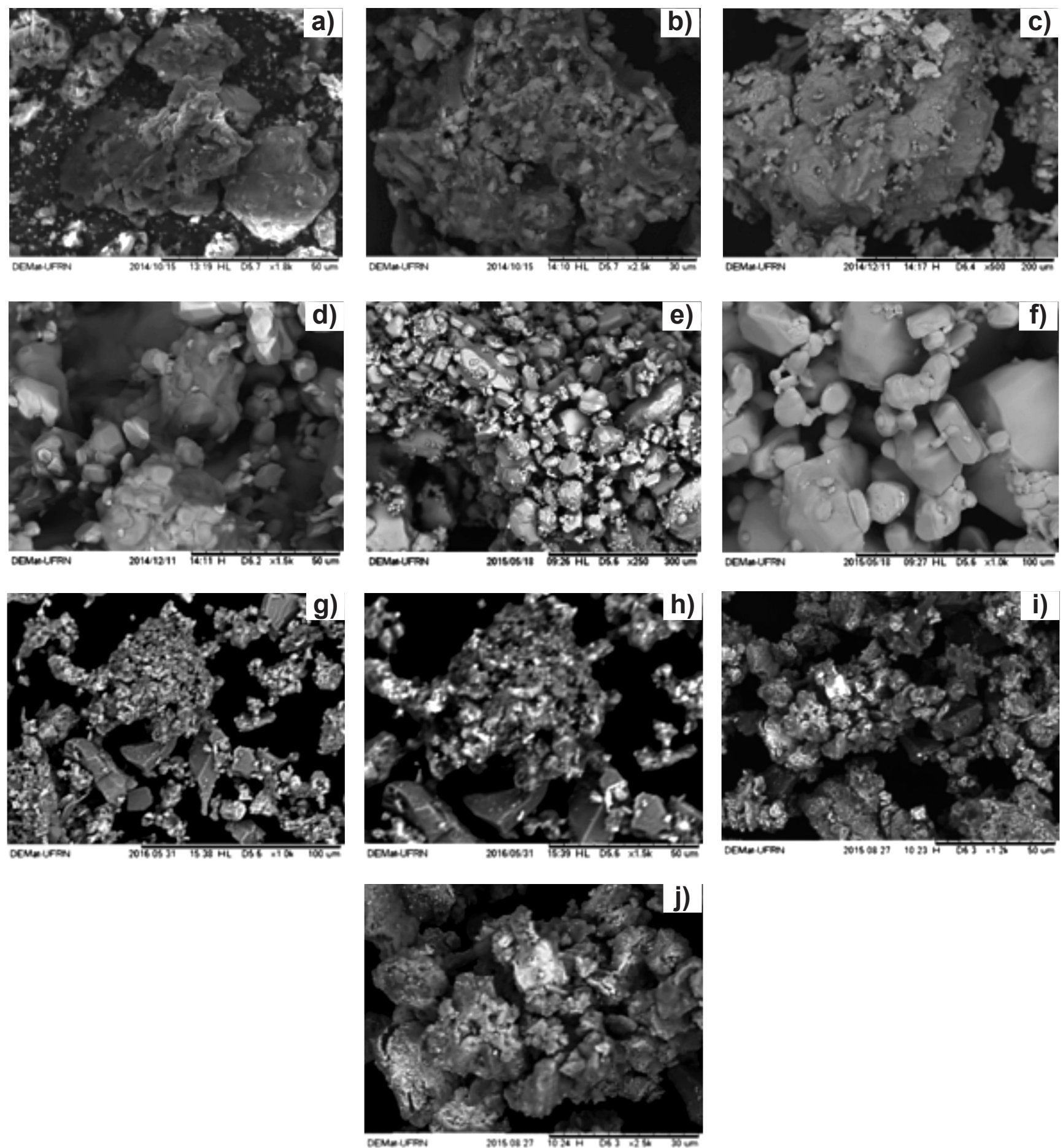

Figure 4: SEM micrographs for: (a,b) A.C; (c,d) AHM; (e,f) $\mathrm{Mo}_{2} \mathrm{C}$; (g,h) Mo $\mathrm{M}_{2}$ /A.C; and (i,j) bimetallic Mo-Ni carbide over A.C.

[Figura 4: Micrografias obtidas por microscopia eletrônica de varredura do: (a,b) carvão ativado; (c,d) heptamolibdato de amônio; (e,f) $\mathrm{Mo}_{2} \mathrm{C}$; $(g, h) \mathrm{Mo}_{2} \mathrm{C} / \mathrm{C} . \mathrm{A}$.; e $(i, j)$ carbeto de $\left.\mathrm{Mo}-\mathrm{Ni} / \mathrm{C} . \mathrm{A}.\right]$

presented higher surface area upon supporting over A.C in comparison to the pure carbide. The attained values for pure $\mathrm{Mo}_{2} \mathrm{C}$ were close to the ones observed in $[19,20]$, which ranged from 49 to $51 \mathrm{~m}^{2} \cdot \mathrm{g}^{-1}$ [21], showing that the activity of molybdenum carbide for benzene hydrogenation increased with increasing surface area and smaller particles of $\mathrm{Mo}_{2} \mathrm{C}$ crystals. The addition of the second metal to the supported carbide powder decreased the observed surface area, as can be observed upon comparing $\mathrm{Mo}_{2} \mathrm{C} / \mathrm{A} . \mathrm{C}$ and Mo-Ni carbide/ A.C. On the other hand, Ni presence in Mo catalyst had a significant promoting effect, which may compensate the loss in surface area. Xiao et al. [22] studied the synthesis of bimetallic Mo-Co carbides and achieved surface areas of 15.5-39.6 $\mathrm{m}^{2} . \mathrm{g}^{-1}$, which is far less than in this work, due to the lack of support in their work. However, their values are close to the pure unsupported powder presented here. 
Table III - Surface area and pore size evaluation.

[Tabela III - Área superficial e tamanho de poro obtidos pelo método BET.]

\begin{tabular}{cccc}
\hline Sample & $\mathrm{S}_{\mathrm{BET}}\left(\mathrm{m}^{2} \cdot \mathrm{g}^{-1}\right)$ & $\mathrm{Vp}\left(\mathrm{cm}^{3} \cdot \mathrm{g}^{-1}\right)$ & $\mathrm{Aps}(\mathrm{nm})$ \\
\hline Carbon & 13 & 0.03 & 4.6 \\
$\mathrm{~A} . \mathrm{C}$ & 141 & 0.12 & 3.5 \\
$\mathrm{Mo}_{2} \mathrm{C}$ & 45 & 0.06 & 5.8 \\
$\mathrm{Mo}_{2}$ C/A.C & 73 & 0.08 & 4.3 \\
$\begin{array}{c}\text { Mo-Ni } \\
\text { carbide/A.C }\end{array}$ & 44 & 0.05 & 4.6 \\
\hline
\end{tabular}

Notes: $S_{B E T}$ - surface area calculation according to BET methodology; Vp - specific pore volume; Aps - average pore size.
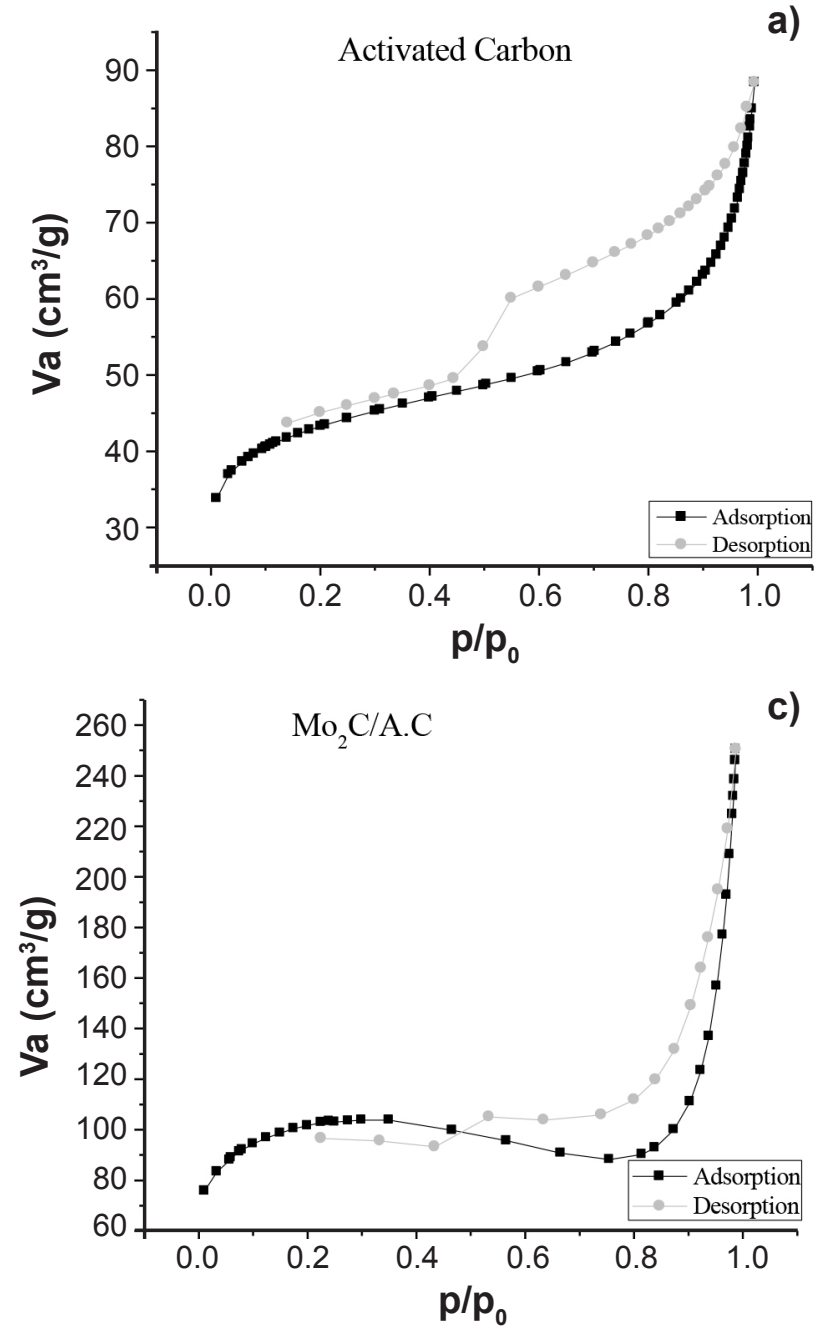

Fig. 5a presents adsorption/desorption isotherm for activated carbon. A type IV isotherm can be identified. This is obtained when there is capillary condensation, where a monolayer is formed previously from pore filling. This isotherm is characteristic of samples with meso and macropores, where the adsorption in multilayers is possible, though limited by the dimension of the pores [23]. In Fig. 5b, adsorption/desorption isotherm for the pure molybdenum carbide powder is presented. A type II isotherm can be attributed to this material. This is the most common isotherm for non-porous systems adsorption measurements [23]. Figs. $5 \mathrm{c}$ and $5 \mathrm{~d}$ present this evaluation for the supported carbide and for the bimetallic supported carbide, respectively. It
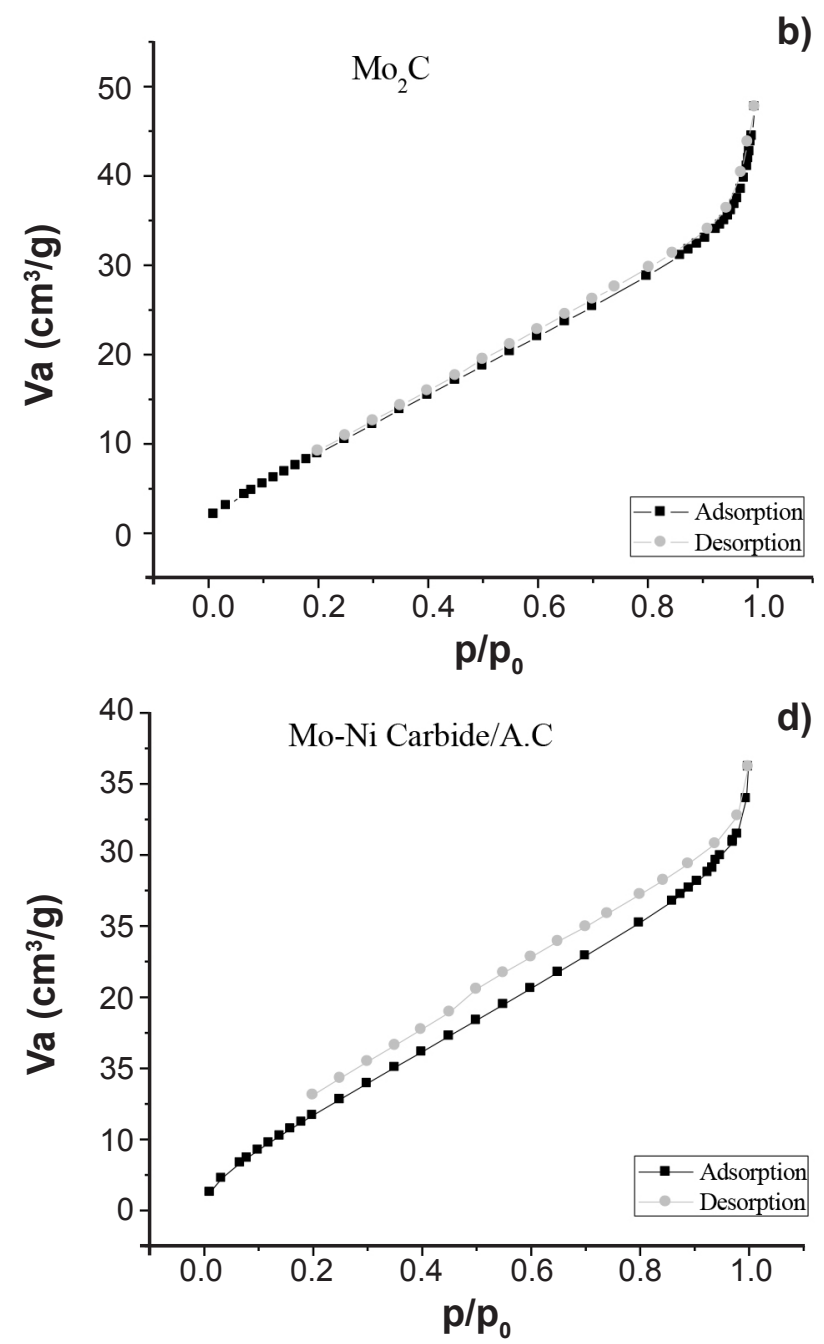

Figure 5: Adsorption/desorption isotherms for: (a) A.C; (b) $\mathrm{Mo}_{2} \mathrm{C}$; (c) $\mathrm{Mo}_{2} \mathrm{C} / \mathrm{A} . \mathrm{C}$; and (d) Mo-Ni carbide/A.C.

[Figura 5: Isotermas de adsorção/dessorção do: (a) C.A.; (b) $\mathrm{Mo}_{2} \mathrm{C}$; (c) $\mathrm{Mo}_{2} \mathrm{C} / \mathrm{C}$.A.; e (d) carbeto de Mo-Ni/C.A.]

Table IV - Particle size evaluation.

[Tabela IV - Distribuição granulométrica dos materiais sintetizados.]

\begin{tabular}{ccccc}
\hline Sample & Diameter $10 \%(\mu \mathrm{m})$ & Diameter $50 \%(\mu \mathrm{m})$ & Diameter 90\% $(\mu \mathrm{m})$ & Average diameter* $(\mu \mathrm{m})$ \\
\hline $\mathrm{Mo}_{2} \mathrm{C}$ & 5.81 & 36.69 & 246.20 & 85.66 \\
$\mathrm{Mo}_{2} \mathrm{C} /$ A.C. & 8.07 & 26.78 & 62.05 & 35.93 \\
Mo-Ni carbide/A.C. & 14.93 & 29.37 & 54.52 & 45.10 \\
\hline
\end{tabular}


can be noted that the presence of the support promoted significant changes in the adsorption/desorption behavior of molybdenum carbide, even though a type II isotherm is still observed.

Particle size evaluation: Table IV presents particle size evaluation data for all materials. The graphics of Fig. 6 present particle size distribution curves. A bimodal particle
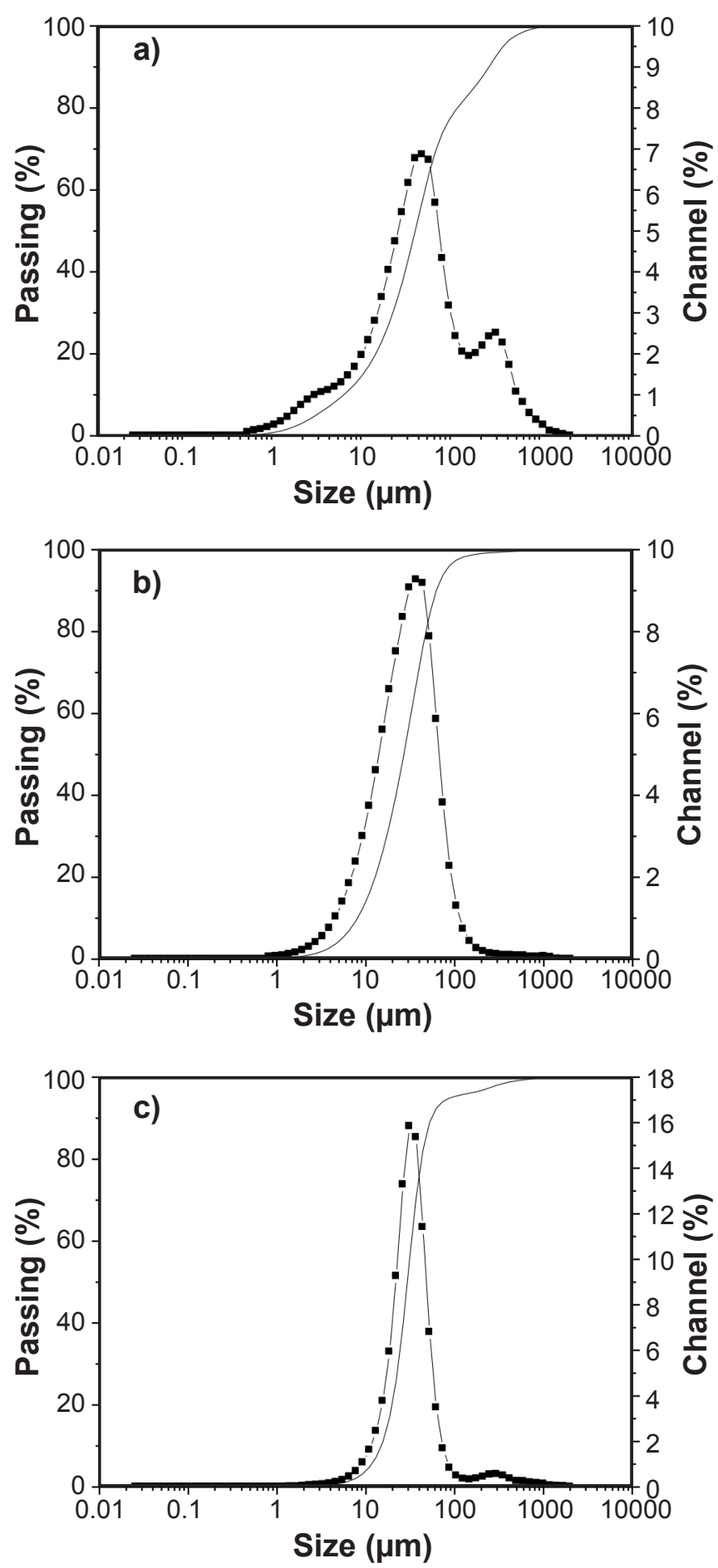

Figure 6: Particle size distribution curves for: (a) $\mathrm{Mo}_{2} \mathrm{C}$; (b) $\mathrm{Mo}_{2} \mathrm{C} /$ A.C; and (c) Mo-Ni carbide/A.C.

[Figura 6: Curvas de distribuição dos diâmetros das partículas do: (a) $\mathrm{Mo}_{2} \mathrm{C}$; (b) $\mathrm{Mo}_{2} \mathrm{C} / \mathrm{C} . \mathrm{A}$.; e (c) carbeto de Mo-Ni/C.A.] size distribution was obtained for unsupported $\mathrm{Mo}_{2} \mathrm{C}$ (Fig. 6a). It was verified that half the sample presented particle sizes bellow $36.69 \mu \mathrm{m}$ and that $90 \%$ of the material presented diameters bellow $246.20 \mu \mathrm{m}$, producing an average particle size of $85.66 \mu \mathrm{m}$ (particle volume). $\mathrm{Mo}_{2} \mathrm{C} / \mathrm{A} . \mathrm{C}$, on the other hand, presented a modal particle size distribution, with 50\% of the sample with diameters below $26.78 \mu \mathrm{m}$ and $90 \%$ with diameters bellow $62.50 \mu \mathrm{m}$ (Fig. 6b). The average diameter for this distribution based on particle volume was $35.93 \mu \mathrm{m}$. This decrease in particle size and smoother distribution may be attributed to the support. Bimetallic Mo-Ni carbide supported on A.C presented, as well as the unsupported powder, a bimodal distribution with half the volume presenting diameters below $29.37 \mu \mathrm{m}$ and $90 \%$ of the sample presenting diameters below $54.52 \mu \mathrm{m}$, which accounted for an average particle size of $45.10 \mu \mathrm{m}$ (Fig. 6c). As it can be noted, this result is in agreement with the crystal sizes estimates presented in Table I, where it was verified that the addition of the second metal produced slightly larger particles, probably due to some extent of it being present in the crystal structure of the carbide.

\section{CONCLUSIONS}

In this paper sewage sludge derived carbonaceous material was used as support for several catalysts. Previously from its final use, the carbon powder was subject to chemical and thermal treatment. Thermal treatment conditions were defined on the basis of thermogravimetric analysis, which indicated thermal stability over $500{ }^{\circ} \mathrm{C}$ under $\mathrm{N}_{2}$ atmosphere. This condition was applied on the thermal treatment that followed the chemical activation with $\mathrm{KOH}$ step. XRD analysis confirmed this material's partially crystalline structure and SEM images revealed a porous morphology. BET and adsorption/desorption isotherms confirmed SEM evaluation and indicated a type IV material, which is mainly mesoporous. From these results, it was possible to verify the significant increase in surface area (from 13 to $141 \mathrm{~m}^{2} \cdot \mathrm{g}^{-1}$ ) in comparison to the non-activated material and testify for the effectiveness and viability of using $\mathrm{KOH}$ and the described activation method for producing activated carbon from domestic sewage sludge residue. This is an important achievement of this work, as technological applications were found for a residue, attributing value to it. Gas-solid reaction TPR method was applied for the synthesis of unsupported and supported powders. XRD and XRF data confirmed the obtained crystal phases and composition of the molybdenum materials. The supported powders indicated the presence of A.C derived phases, as well as $\mathrm{Mo}_{2} \mathrm{C}$ and $\mathrm{Ni}$ phases (for the bimetallic carbide). The support presence increased $\mathrm{Mo}_{2} \mathrm{C}$ 's surface area (45 to $73 \mathrm{~m}^{2} \cdot \mathrm{g}^{-1}$ ), however, the addition of the second metal promoted a decrease in this property. On the other hand, Ni presence plays a major role on the catalytic activity of Mo derived powders. SEM evaluation for these materials indicated the presence of platelets and agglomerates, typical from $\mathrm{Mo}_{2} \mathrm{C}$ phase, and porous structures originated from A.C phase. From the 
obtained data, good catalyst behavior is expected for these materials, especially due to the significant increase in surface area of supported materials.

\section{ACKNOWLEDGMENTS}

We thank CAPES and UFRN Chemical Engineering Post-Graduation Program for providing support to develop this research.

\section{REFERENCES}

[1] R.B. Levy, M. Boudart, Sci. 181 (1973) 547.

[2] J.S. Lee, M. Boudart, Appl. Cat. 19 (1985) 207.

[3] S.Z. Li, J.S. Lee, T. Hyeon, K.S. Suslick, Appl. Cat. A 184 (1999) 1.

[4] I. Borovinskaya, T. Ignatieva, V. Vershinnikov, A. Nanda Kumar, K.M. Kurokawa, Tungsten Carbide-Processing and Applications, Intech, London (2012).

[5] Z. Fang, Z. Wang, T. Ryu, K. Hwang, H. Sohn, Int. J. Refract. Met. Hard Mater. 27 (2009) 288.

[6] J.S. Lee, S.T. Oyama, M. Boudart, J. Catal. 106 (1987) 125.

[7] I.M.F.S. Silva, in Proc. $10^{\circ}$ Congr. Bras. Catál., Salvador, Brasil (1999).

[8] A. Claudino, "Preparação de carvão ativado a partir de turfa e sua utilização na remoção de poluentes", Diss. Mestr., Universidade Federal de Santa Catarina, Florianópolis, Brasil (2003).

[9] F. Rodríguez-Reinoso, M. Molina-Sabio, Adv. Colloid Interface Sci. 76/77 (1998) 271.

[10] T. Xiao, H. Wang, Da Jianwen, K.S. Coleman, M.L.H. Green, J. Catal. 211(2002) 183.

[11] M.M. Pedroza, "Bio-óleo e Biogás da degradação termoquímica de lodo de esgoto doméstico em cilindro rotativo", Tese Dr., Universidade Federal do Rio Grande do Norte, Natal, Brasil (2011).

[12] M.O.A. Méndez, "Síntese de materiais carbonosos ativados a partir de coque de petróleo", Diss. Mestr., Universidade Estadual de Campinas, Campinas, Brasil (2005).

[13] F.G. Mendonça, E.O. Jardim, R.M. Lago, J.C. Tristão, in Proc. 36a Reun. Anual Soc. Bras. Quím., S. Paulo, Brasil (2013).

[14] L.A. Solano, M.A.L. Ródenas, D.C. Amorás, Carbon 41 (2003) 267.

[15] K.K.P. Gomes, "Síntese e caracterização do carbeto de molibdênio nanoestruturado para fins catalíticos na reação de oxidação parcial do metano", Diss. Mestr., Universidade Federal do Rio Grande do Norte, Natal, Brasil (2006).

[16] E.P. Polo, J. Brito, J. Mol. Catal. A: Chem. 281 (2008) 85.

[17] J.R.G. Vieira, "Avaliação de catalisadores a base de carbeto e nitreto de molibdênio na obtenção de lactitol via hidrogenação da lactose", Tese Dr., Universidade Federal do Rio Grande do Norte, Natal, Brasil (2010).

[18] J. Romanos, M. Beckner, T. Rash, L. Firlej, B. Kuchta, P. Yu, G. Suppe, C. Wexler, P. Pfelfer, Nanotechnol. 23 (2012).

[19] L. Volpe, M. Boudart, J. Solid State Chem. 59 (1985) 332.

[20] J.S. Choi, G. Bugli, G.D. Mariadassou, J. Catal. 193 (2000) 238.

[21] E. Furimsky, Appl. Catal. A: General 240 (2003) 1.

[22] T.-C. Xiao, A.P. York, H. Al-Megren, H.-T. Wang, C. Williams, M. Green, J. Catal. 202 (2001) 100.

[23] G. Ertl, H. Knözinger, J. Weitkamp, Handbook of Heterogeneous Catalysis, Wiley-VCH Verlag, Weinheim (2008).

(Rec. 16/11/2016, Rev. 21/02/2017, 10/04/2017, 06/07/2017, Ac. 15/08/2017) 